\title{
Dialogical strategies of science communicators
} (Science Communication)

\section{AUTHOR}

Nina Wicke

\section{KEYWORDS}

NGOs, non-scientific communicators, alternative science communicators, strategic communication, dialogical strategies, dialogic communication

\section{BRIEF DESCRIPTION}

According to Taylor et al. (2001), dialogue can be defined ,as a tool for effective and mutually rewarding interpersonal communication" (p. 267) and refers to "any negotiated exchange of ideas and opinions" (Kent \& Taylor, 1998, p. 325), whereby all parties in a relationship strive to engage in an honest, open and ethically communicative give and take (Bortree \& Seltzer, 2009). From a public relations perspective, dialogue is a necessary tool to build an effective relationship with the public (Kent \& Taylor, 1998). Dialogical strategies therefore serve to build and maintain dynamic and lasting relationships with publics (Kent \& Taylor, 1998).

\section{THEORETICAL FOUNDATION}

Many studies investigating the dialogical strategies of organizations on the Internet refer in terms of their theoretical foundation to the preliminary work of Kent and Taylor (1998) and Taylor et al. (2001) (e. g. Bortree \& Seltzer, 2009; Yang \& Taylor, 2010). Kent and Taylor (1998) developed five dimensions, so-called "principles of dialogue" (Taylor et al., 2001, p. 269), which can be utilized by organizations in their strategically designed websites in order to engage in dialogical relationships. Among these principles are:

1. Ease of interface: This point refers to the usability of a site which is a prerequisite for online dialogue. If visitors do not have an easy time navigating a site and finding information, they will not have a positive experience at the website and may not use it again.

2. Usefulness of information: This principle is relevant because it clarifies the reason for visiting a website. Visitors turn to a site when it provides them with information that is useful, trustworthy, and of lasting value.

3. Conservation of visitors: The goal of websites should be to keep visitors on their own site and not to encourage them to visit other sites, e. g. through advertisements.

4. Generation of return visits: A relationship can only be established by users who are encouraged to return and visit the website on a regular basis.

5. Dialogic loop: Websites have to offer twoway communication (interactivity) in order to be fully dialogic.

Other studies adapted the theoretical framework and modified it for application to different research objects such as social media platforms (Bortree \& Seltzer, 2009; Yang \& Taylor, 2010). For instance, the study by Bortree \& Seltzer (2009) extended it by adding organization engagement as a new strategy, since organizations can also encourage dialogue via posts on their own sites (e. g. walls and discussion boards). Besides the dialogic strategies, their outcomes are often identified and coded as well.

\section{EXAMPLE STUDIES}

Bortree \& Seltzer (2009); Cho et al. (2014); Reber \& Kim (2006); Taylor et al. (2001); Waters et al. (2009); Waters \& Jamal (2011); Yang \& Taylor (2010) 
INFORMATION ON BORTREE \& SELTZER, 2009

Authors: Denise Sevick Bortree \& Trent Seltzer Research objective: "This study sought to determine to what degree advocacy organizations are utilizing dialogic strategies on their social networking profiles as well as the degree to which these strategies are related to actual dialogic outcomes" (p. 317).

Object of analysis: 50 Facebook profiles of environmental advocacy groups

\section{Timeframe of analysis: -}

\section{INFORMATION ABOUT VARIABLES}

Variable name/definition: Dialogic strategies Level of analysis: Facebook page

Values:

- Links to organization homepage

- Number of advertisements on a site

- Use of applications

- Ease of donations

- Join now option

- Offers of regular information through email

- Profile sharing

- Content sharing

- Organization comments in dialogic spaces (i. e. wall and discussion boards)

Scale of measurement: Nominal (Present/absent) Reliability: Intercoder reliability according to Scott's Pi: .61 to .87

\section{Codebook: -}

Variable name/definition: Outcomes of dialogic communication

Level of analysis: Facebook page

Values:

- User posts (number of user posts on wall and discussion board)

- Network activity (number of user posts in one week)

- User responses to others (number of user posts in response to inquiries by the organization or others)

- Organization response to users (number of organization posts in response to user inquiries)

- Network extensiveness (total number of friends or fans)

- Network growth (one week increase in number of friends or fans)

Scale of measurement: Metric

Reliability: Intercoder reliability according to Holsti: $90 \%$ - $100 \%$

\section{Codebook: -}

INFORMATION ON YANG \& TAYLOR, 2019

Authors: Aimei Yang \& Maureen Taylor

Research questions: RQ1: How do Chinese ENGOs' websites incorporate features that facilitate interaction? RQ2: How do Chinese ENGOs' websites provide information to key stakeholders (members, volunteers, general public, and the media)? RQ3: How do Chinese ENGOs' websites incorporate relationship-building features?

Object of analysis: 68 Chinese ENGO's websites Timeframe of analysis: -

\section{INFORMATION ABOUT VARIABLES}

Variable name/definition: Website features

Level of analysis: Website

Values:

- $\quad$ Ease of interaction (site map, major link to rest of site, search engine box)

- Usefulness of information to members/volunteers (details of how to become affiliated, how to contribute money, links (email, telephone) to organization leaders, chat room/ BBS/Blog, links to affiliate websites)

- Usefulness of information to general public (tips of how to practice environmentally friendly activities in everyday life, tips of how to lead a healthy life, games and other entertainment function)

- Usefulness of information to the media (press release room/search engine, FAQ section aimed at media, news published or aired about the organization, editorial stories written by organization staff, organizationin-action photos/stories, downloadable graphics/video/other material, organization fact sheets, organization logos for use in publication, clearly stated position on policy issues, organization perspective on current issues/ trends, annual reports/financial)

- Relationship-building (opportunity for userresponse, opportunity to vote on issues, survey to voice opinion on issues, offers regular information through email, positing calendar of events)

- Mission statement (statement of mission/ organization value/goals from amoral authority perspective, statement of mission/organization value/goals from a grassroots perspective) 
Scale of measurement: Nominal $(1=$ absence; 2 = linked through at least three levels of hyperlinks from the front page; $3=$ linked through at least two levels of hyperlinks from the front page; $4=$ placed on the front page)

Reliability: Intercoder reliability according to Scott's Pi: .77 to 1.00

$(\mathrm{M}=.84)$

Codebook: -

\section{REFERENCES}

Bortree, D. S., \& Seltzer, T. (2009). Dialogic strategies and outcomes: An analysis of environmental advocacy groups' Facebook profiles. Public Relations Review, 35(3), 317-319. https://doi.org/10.1016/j.pubrev.2009.05.002

Cho, M., Schweickart, T., \& Haase, A. (2014). Public engagement with nonprofit organizations on Facebook. Public Relations Review, 40(3), 565-567. https:// doi.org/10.1016/j.pubrev.2014.01.008

Kent, M. L., Taylor, M. (1998). Building dialogic relationships through the World Wide Web. Public Relations Review, 24(3), 321-334.

Reber, B. H., \& Kim, J. K. (2006). How activist groups use websites in media relations: Evaluating online press rooms. Journal of Public Relations Research, 18(4), 313-333. https://doi.org/10.1207/s1532754xjprr1804_2

Taylor, M., Kent, M. L., \& White, W. J. (2001). How activist organizations are using the Internet to build relationships. Public Relations Review, 27(3), 263-284. https:// doi.org/10.1016/S0363-8111(01)00086-8

Waters, R. D., Burnett, E., Lamm, A., \& Lucas, J. (2009). Engaging stakeholders through social networking: How nonprofit organizations are using Facebook. Public Relations Review, 35(2), 102-106. https:// doi.org/10.1016/j.pubrev.2009.01.006

Waters, R. D., \& Jamal, J. Y. (2011). Tweet, tweet, tweet: A content analysis of nonprofit organizations' Twitter updates. Public Relations Review, 37(3), 321-324. https:// doi.org/10.1016/j.pubrev.2011.03.002

Yang, A., \& Taylor, M. (2010). Relationship-building by Chinese ENGOs' websites: Education, not activation. Public Relations Review, 36(4), 342-351. https:// doi.org/10.1016/j.pubrev.2010.07.001 